\title{
EVALUASI KONDISI DEMOGRAFI SECARA TEMPORAL DI PROVINSI BENGKULU:

\author{
Rasio Jenis Kelamin, Rasio Ketergantungan, Kepadatan Peduduk
}

\author{
Afid Nurkholis \\ Email: afidnurkholis@gmail.com
}

\begin{abstract}
ABSTRAK
Pengukuran terhadap karakteristik demografi dilakukan untuk mengetahui nilai kuantitatif komponen tersebut. Karakteristik yang diukur di penelitian ini adalah jumlah penduduk, rasio jenis kelamin, rasio beban tanggungan, dan kepadatan penduduk. Analisis temporal digunakan untuk mengetahui perbedaan setiap parameter pada jangka waktu tertentu (tahun 1971, 1980, 1990, 2000, 2010). Selanjutnya, nilai tersebut dapat diukur secara kualitatif sebagai gambaran tingkat atau kondisi karakteristik demografi. Hasil pengukuran karakteristik demografi Provinsi Bengkulu merupakan hal yang penting. Hal ini berkaitan dengan pembangunan sumber daya manusia. Pembangunan sudah seharusnya mengarah terhadap kepentingan manusia tanpa merusak lingkungan. Komponen dasar mengenai penduduk dapat dilihat berdasarkan karakteristik demografi. Oleh karena itu, evaluasi kondisi demografi ini merupakan hal penting yang dapat digunakan sebagai dasar evaluasi sumberdaya manusia.
\end{abstract}

Katakunci: kondisi demografi, rasio jenis kelamin, rasio ketergantungan, kepadatan peduduk, Provinsi Bengkulu

\section{A. Pendahuluan}

\section{Latar Belakang}

Demografi adalah ilmu yang mempelajari peduduk di suatu wilayah terutama mengenai struktur penduduk (jumlah, komposisi, persebaran) dan proses penduduk (kelahiran, kematian, migrasi) (IUSPP dalam Mantra, 2000). Sementara itu, studi kependudukan berbeda dengan demografi dalam hal pendektan yang digunakan. Kependudukan dapat dikatakan lebih luas dari kajian demografi (Mantra, 2000) karena dalam memahami struktur dan proses penduduk melibatkan faktor-faktor nondemografis seperti sosial, ekonomi, dan politik penduduk. 
Tulisan ini akan menganalis kondisi demografi Provinsi Bengkulu. Studi demografi dipilih karena tulisan ini akn mengkaitkannya dengan pendekatan geografi yang berupa spasial dan temporal. Pendekatan spasial yang dimaksud adalah hubungan karakteristik demografi Provinsi Bengkulu dengan keadaan sumberdaya yang dimiliki baik manusia maupun alam dan hubungan keruangannya dengan yang lebih general di Indonesia. Pendekatan temporal adalah menganalisis kondisi demografi dari tahun ketahun yaitu pada tahun 1971, 1980, 1990, 2000, dan 2010. Pendekatan spasial dan temporal tersebut mampu mengevaluasi dan menganalisis kondisi demografi Provinsi Bengkulu secara komprehensif.

Tulisan ini akan mengevaluasi variable struktur demografi yang terdiri dari jumlah dan komposisi. Variabel dalam studi demografi terdiri dari dua yaitu struktur dan proses demografi. Struktur demografi dipilih karena berkaitan dengan terbatasnya waktu penelitian yang dilakukan. Selain itu, struktur demografi merupakan hasil dari proses-proses demografi yang berlangsung, sehingga hasil yang didapatkan dapat menjelaskan atau sebagai pencerminan proses yang terjadi.

Pengukuran terhadap karakteristik demografi dilakukan untuk mengetahui nilai kuantitatif komponen tersebut. Karakteristik yang diukur di penelitian ini adalah jumlah penduduk, rasio jenis kelamin, rasio beban tanggungan, dan kepadatan penduduk. Selanjutnya, nilai tersebut dapat diukur secara kualitatif sebagai gambaran tingkat atau kondisi karakteristik demografi. Hasil pengukuran karakteristik demografi Provinsi Bengkulu merupakan hal yang penting. Hal ini berkaitan dengan pembangunan sumber daya manusia. Pembangunan sudah seharusnya mengarah terhadap kepentingan manusia tanpa merusak lingkungan. Komponen dasar mengenai penduduk dapat dilihat berdasarkan karakteristik demografi. Oleh karena itu, evaluasi kondisi demografi ini merupakan hal penting yang dapat digunakan sebagai dasar evaluasi sumberdaya manusia. 


\section{Tujuan}

1. Menganalisis rasio jenis kelamin Provinsi Bengkulu pada tahun 1971, 1980, 1990, 2000, dan 2010.

2. Menganalisis rasio ketergantungan Provinsi Bengkulu pada tahun 1971, 1980, 1990, 2000, dan 2010.

3. Menganalisis kepadatan peduduk Provinsi Bengkulu pada tahun 1971, 1980, 1990, 2000, dan 2010.

\section{B. Tinjauan Pustaka}

\section{Rasio Jenis Kelamin}

Rasio jenis kelamin adalah perbandingan jumlah antara penduduk dengan jenis kelamin laki-laki dengan perempuan (Mantra, 2000). Pengukuran ini perlu dilakukan untuk mengetahui perbandingan jumlah dua jenis kelamin baik pada beberapa wilayah (spasial) maupun beberapa waktu (temporal). Pengukuran rasio jenis kelamin dapat dilakukan berdasarkan jumlah penduduk total, penduduk umur 0 tahun (sex ratio at birth), dan setiap kelompok umur. Seara umum, rumus perhitungan rasio ini adalah sebagai berikut:

$$
\mathrm{SR}=\frac{\text { Jumlah Penduduk Laki-Laki }}{\text { Jumlah Penduduk Perempuan }} \times 100
$$

Kondisi rasio jenis kelamin di suatu daerah dapat dipengaruhi oleh beberapa hal, yaitu:

a. Pola mortalitas dan fertilitas antara Penduduk Laki-laki dan permpuan.

b. Pola migrasi penduduk laki-laki dan perempuan.

\section{Rasio Beban Tanggungan}

Rasio ketergantungan atau dependency ratio (DR) adalah nilai yang menunjukkan seberapa banyak penduduk peroduktif menanggung penduduk yang tidak produktif (Mantra, 2000). Rasio ini didapatkan dengan membandingkan jumlah penduduk tidak produktif (usia $<15$ tahun dan $>64$ tahun) dengan penduduk produktif (usia 15 - 64 tahun). 


$$
\text { Rasio Beban Tanggungan }=\frac{P_{0-14}+P_{65+}}{P_{15-64}} \times 100
$$

\section{Kepadatan Penduduk}

Kepadatan penduduk merupakan jumlah penduduk per satuan wilayah tertantu (Mantra, 2000). Kepadatan penduduk wilayah terdiri dari berbagai konsep, seperti kasar, fisiologis, agraris, dan ekonomi. Perhitungan kepadatan penduduk adalah sebagai berikut:

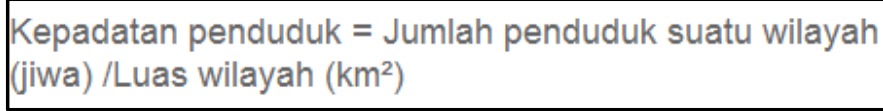

Kepadatan penduduk fisiologis = Jumlah penduduk (jiwa) / Luas lahan pertanian $\left(\mathrm{km}^{2}\right)$

Kepadatan penduduk agraris = Jumlah penduduk petani (jiwa) $/$ Luas lahan pertanian $\left(\mathrm{km}^{2}\right)$

\section{Pembahasan}

\section{Jumlah Penduduk}

Jumlah penduduk Provinsi Bengkulu dari tahun 1971 - 2010 terus mengalami peningkatan (Tabel 1). Penduduk pada tahun 1971 adalah 509,216 jiwa, sedangkan pada tahun 2010 mencapai 1,715,518 jiwa. Secara demografi, meningkatnya jumlah penduduk tersebut diakibatkan oleh jumlah kelahiran yang meningkat, kematian yang rendah, dan migrasi masuk yang lebih besar dibandingkan migrasi keluar.

Tabel 1: Jumlah Penduduk dan Seks Ratio Tahun 1971-2010

\begin{tabular}{|l|r|r|r|r|r|}
\hline Tahun/Keterangan & $\mathbf{1 9 7 1}$ & $\mathbf{1 9 8 0}$ & $\mathbf{1 9 9 0}$ & $\mathbf{2 0 0 0}$ & $\mathbf{2 0 1 0}$ \\
\hline Penduduk laki-laki & $\mathbf{2 6 2 , 1 1 3}$ & 389,902 & 605,579 & 793,120 & 877,159 \\
\hline Penduduk perempuan & $\mathbf{2 4 7 , 1 0 3}$ & 377,886 & 573,293 & 768,985 & 838,359 \\
\hline Jumlah penduduk & 509,216 & 767,788 & $1,178,872$ & $1,562,105$ & $1,715,518$ \\
\hline Seks ratio & 106 & 103 & 106 & 103 & 105 \\
\hline
\end{tabular}

Sumber: BPS dengan pengolahan, 2016 
Jumlah kelahiran dapat meningkat karena ekonomi masyarakat yang juga meningkat. Hal ini berkaitan dengan pemenuhan kebutuhan individu seperti sandang, pangan, dan papan. Seseorang yang mampu lebih dari mencukupi kebutuhan dasarnya akan memiliki jumlah anak yang lebih. Kematian dapat menurun dikarenakan tingkat kesadaran kesehatan yang tinggi (faktor pendidikan), fasilitas kesehatan yang memadai, dan dukungan pemerintah terhadap kesehatan penduduk. Tahun 1970 an dapat dikatakan teknologi kesehatan maupun akses pendidikan belum berkembang seperti tahun 2000 an. Hal ini dapat menjadi contoh pengaruhnya terhadap angka kematian yang dapat diartikan kematian bayi atau lansia (usia harapan hidup). Angka migrasi masuk maupun keluar dipengaruhi oleh sumberdaya yang berkaitan dengan mata pencaharian di Provinsi Bengkulu. Semakin modern atau banyaknya lapangan pekerjaan di daerah ini maka penduduk akan menetap dan migrasi masuk akan tinggi. Penelitian mendetil mengenai pertumbuhan penduduk dengan menyajikan data demografi (kelahiran, kematian, migrasi) yang rinci perlu dilakukan untuk melengkapi analisis ini.

\section{Gambar 1: Piramida Penduduk 1971-2010}
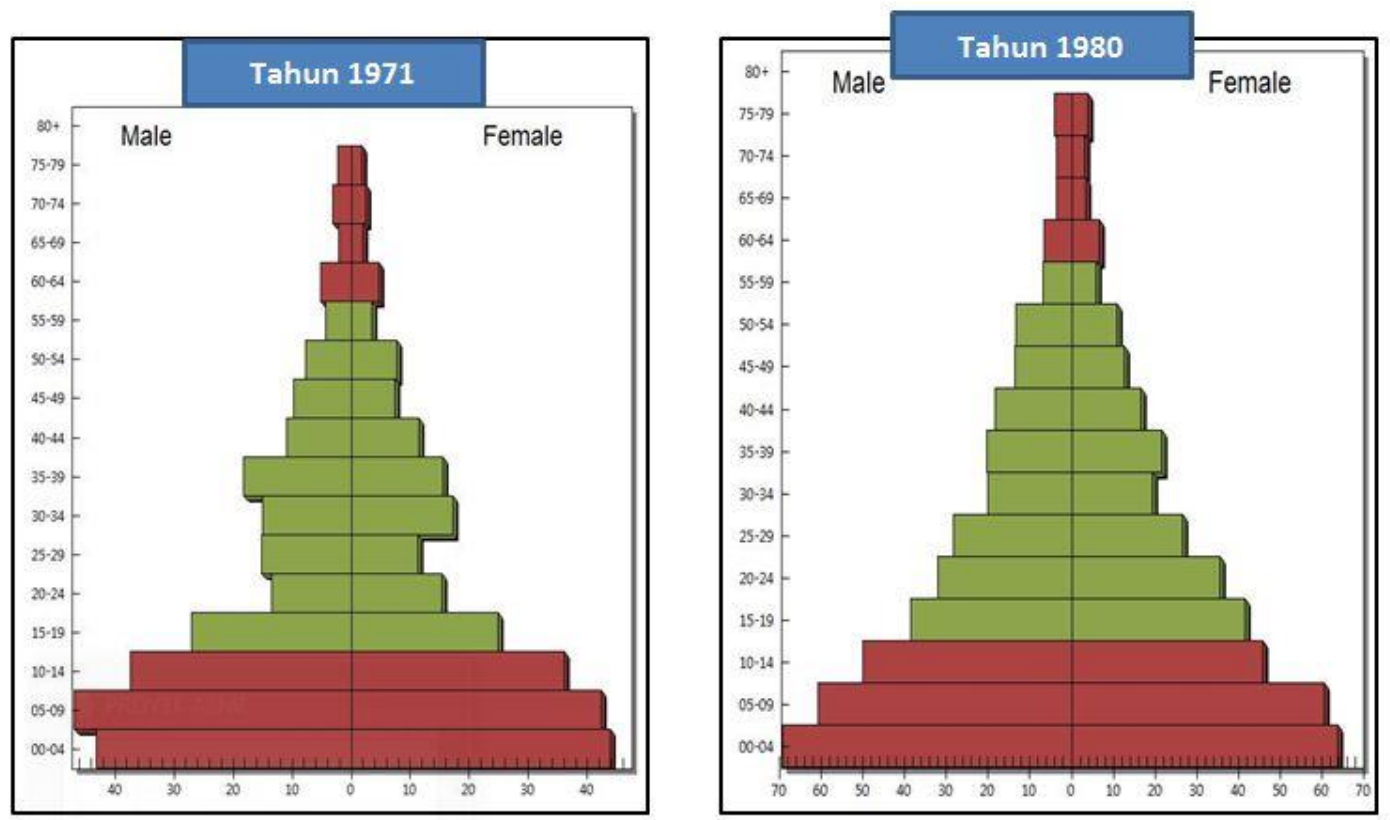

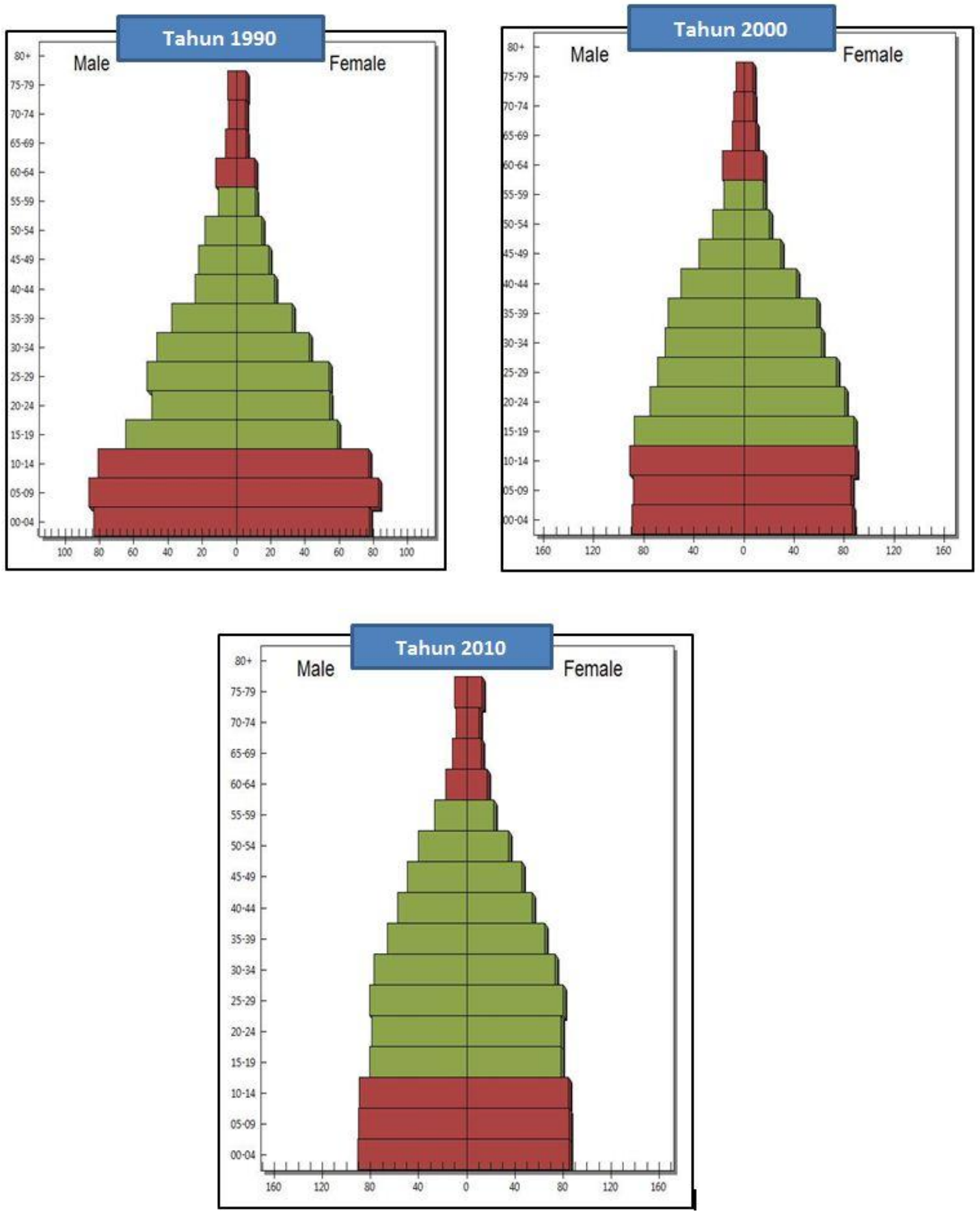

Sumber: BPS dengan pengolahan, 2016 
Tabel 2: Jumlah Penduduk Berdasarkan Jenis Kelamin Tahun 1971-2010

\begin{tabular}{|c|c|c|c|c|c|c|c|c|c|c|c|c|c|c|c|}
\hline \multirow{2}{*}{ Umur } & \multicolumn{3}{|c|}{1971} & \multicolumn{3}{|c|}{1980} & \multicolumn{3}{|c|}{1990} & \multicolumn{3}{|c|}{2000} & \multicolumn{3}{|c|}{2010} \\
\hline & L & $P$ & Jumlah & L & $\mathrm{P}$ & Jumlah & L & $P$ & Jumlah & L & $P$ & Jumlah & L & $\mathrm{P}$ & Jumlah \\
\hline $0-4$ & 43,199 & 43,781 & 86,980 & 69,227 & 63,682 & 132,909 & 83,399 & 77,409 & 160,808 & 89,431 & 86,787 & 176,218 & 90,508 & 85,299 & 175,807 \\
\hline $5-9$ & 46,902 & 42,310 & 89,212 & 60,645 & 60,427 & 121,072 & 86,348 & 82,883 & 169,231 & 88,397 & 85,356 & 173,753 & 90,252 & 84,807 & 175,059 \\
\hline $10-14$ & 37,378 & 36,087 & 73,465 & 50,132 & 45,897 & 96,029 & 80,876 & 76,950 & 157,826 & 91,612 & 89,082 & 180,694 & 89,086 & 84,558 & 173,644 \\
\hline $15-19$ & 27,106 & 24,915 & 52,021 & 38,612 & 41,572 & 80,184 & 64,515 & 58,999 & 123,514 & 87,456 & 87,952 & 175,408 & 81,033 & 78,408 & 159,441 \\
\hline $20-24$ & 13,408 & 15,270 & 28,678 & 32,074 & 35,570 & 67,644 & 49,577 & 54,540 & 104,117 & 75,068 & 80,355 & 155,423 & 78,839 & 78,218 & 157,057 \\
\hline $25-29$ & 15,130 & 11,228 & 26,358 & 28,344 & 26,687 & 55,031 & 52,340 & 54,060 & 106,400 & 69,025 & 73,983 & 143,008 & 80,971 & 80,142 & 161,113 \\
\hline $30-34$ & 14,983 & 17,247 & 32,230 & 19,984 & 19,422 & 39,406 & 46,657 & 42,205 & 88,862 & 63,035 & 61,811 & 124,846 & 76,979 & 73,135 & 150,114 \\
\hline $35-39$ & 18,169 & 15,468 & 33,637 & 20,386 & 21,645 & 42,031 & 37,739 & 32,338 & 70,077 & 60,790 & 58,412 & 119,202 & 66,308 & 64,532 & 130,840 \\
\hline $40-44$ & 11,015 & 11,454 & 22,469 & 18,423 & 16,688 & 35,111 & 24,090 & 22,260 & 46,350 & 50,426 & 41,818 & 92,244 & 57,573 & 54,414 & 111,987 \\
\hline $45-49$ & 9,810 & 7,369 & 17,179 & 13,673 & 12,544 & 26,217 & 22,074 & 18,936 & 41,010 & 36,112 & 29,127 & 65,239 & 49,698 & 45,842 & 95,540 \\
\hline $50-54$ & 7,763 & 7,745 & 15,508 & 13,451 & 10,816 & 24,267 & 18,350 & 14,849 & 33,199 & 24,774 & 20,501 & 45,275 & 40,347 & 34,958 & 75,305 \\
\hline $55-59$ & 4,409 & 3,408 & 7,817 & 6,964 & 5,890 & 12,854 & 10,624 & 10,994 & 21,618 & 15,710 & 15,080 & 30,790 & 26,739 & 22,327 & 49,066 \\
\hline $60-64$ & 5,198 & 4,596 & 9,794 & 6,668 & 6,539 & 13,207 & 12,338 & 10,452 & 22,790 & 16,981 & 15,125 & 32,106 & 17,785 & 16,851 & 34,636 \\
\hline $65-69$ & 2,149 & 1,945 & 4,094 & 3,536 & 3,481 & 7,017 & 6,512 & 5,774 & 12,286 & 9,546 & 9,476 & 19,022 & 11,901 & 12,060 & 23,961 \\
\hline $70-74$ & 3,220 & 2,484 & 5,704 & 3,630 & 3,083 & 6,713 & 4,882 & 5,011 & 9,893 & 8,351 & 7,321 & 15,672 & 8,971 & 9,945 & 18,916 \\
\hline $75+$ & 2,274 & 1,796 & 4,070 & 4,090 & 3,943 & 8,033 & 5,258 & 5,633 & 10,891 & 6,406 & 6,799 & 13,205 & 10,169 & 12,863 & 23,032 \\
\hline Jumlah & 262,113 & 247,103 & 509,216 & 389,839 & 377,886 & 767,725 & 605,579 & 573,293 & $1,178,872$ & 793,120 & 768,985 & $1,562,105$ & 877,159 & 838,359 & $1,715,518$ \\
\hline
\end{tabular}

Sumber: BPS dengan pengolahan, 2016

Piramida penduduk Provinsi Bengkulu menujukkan bentuk yang berbeda dari tahun 1971-2010 (Gambar 1). Piramida tahun 1971, 1980, dan 1990 menunjukkan bentuk yang ekspansif, yaitu penduduk usia dibawah 14 tahun paling besar jumlahnya. Hal ini menandakan fertilitas tinggi dan kemtian tinggi. Sementara itu, tahun 2000 dan 2010 bentuk piramida mulai menuju ke arah konstruktif meskipun belum sempurna. Hal ini berkitan angka fertilitas yang menhurun dan penduduk yang sebelumnya berusia kurang dari 14 tahun telah menjadi penduduk produktif. Keadaan ini mendukung analisis bahwa Bengkulu akan segera mengalami bonus demografi. Jumlah penduduk setiap jenisn kelamin yang digambarkan dalam piramida dapat dilihat pada Tabel 2.

\section{Rasio Jenis Kelamin}

Rasio jenis kelamin adalah perbandingan jumlah antara penduduk dengan jenis kelamin laki-laki dengan perempuan (Mantra, 2000). Pengukuran ini perlu 
dilakukan untuk mengetahui perbandingan jumlah dua jenis kelamin baik pada beberapa wilayah (spasial) maupun beberapa waktu (temporal). Tulisan ini menyajikan rasio jenis kelamin dari tahun 1971 - 2010 pada data kelompok umur lima tahunan dan secara keseluruhan.

Secara umum, penduduk laki-laki di Bengkulu lebih banyak dibandingkan perempuan (Tabel 1). Rasio jenis kelamin dari tahun 1971-2010 berkisar antara 103 hingga paling tinggi 106. Nilai ini diartikan setiap 100 penduduk perempuan akan terdapat 103 atau 106 penduduk laki-laki. Hasil tersebut menunjukkan bahwa jumlah penduduk laki-laki dan perempuan cukup berimbang di Provinsi Bengkulu.

Rasio jenis kelamin setiap kelompok umur lima tahunan dapat dilihat di Tabel 3. Data tersebut menunjukkan bahwa hampir setiap tahun kelahiran penduduk laki-laki selalu lebih banyak dibandingkan perempuan. Hal ini ditunjukkan dengan nilai ratio yang lebih dari 100 pada tahun 1980-2000 di umur 0-4 tahun. Sementara itu, jumlah penduduk laki-laki pada usia 20-24 lebih rendah daripada perempuan. Hal ini dapat diakibatkan oleh penduduk laki-laki yang melakukan migrasi keluar (merantau) untuk bersekolah atau mencari pekerjaan.

Jumlah penduduk lansia juga dapat diketahui polanya melalui tabel tersebut. Penduduk lansia laki-laki di tahun 1971-1980 selalu lebih banyak dibandingkan perempuan. Hal ini menandakan usia harapan hidup laki-laki pada periode tersebut juga tinggi. Sementara itu, jumlah penduduk lansia laki-laki pada tahun 1990 2010 lebih rendah daripada perempuan. Rasio pada tahun 2010 bahkan menunjukkan angka 79. Hal ini menandakan usia harapan hidup perempuan lebih tinggi. Selain itu, nilai ini berarti jumlah janda juga tinggi. Harapan hidup laki-laki yang rendah dapat dipengaruhi oleh pola hidup yang tidak sehat dibandingkan perempuan.

Tabel 3: Rasio Jenis Kelamin Kelompok Umur 5 Tahunan

\begin{tabular}{|c|c|c|c|c|c|}
\hline \multirow{2}{*}{ Umur } & \multicolumn{5}{|c|}{ Sex Ratio } \\
\cline { 2 - 6 } & $\mathbf{1 9 7 1}$ & $\mathbf{1 9 8 0}$ & $\mathbf{1 9 9 0}$ & $\mathbf{2 0 0 0}$ & $\mathbf{2 0 1 0}$ \\
\hline $0-4$ & 99 & 109 & 108 & 103 & 106 \\
\hline $5-9$ & 111 & 100 & 104 & 104 & 106 \\
\hline $10-14$ & 104 & 109 & 105 & 103 & 105 \\
\hline
\end{tabular}




\begin{tabular}{|c|c|c|c|c|c|}
\hline \multirow{2}{*}{ Umur } & \multicolumn{5}{|c|}{ Sex Ratio } \\
\cline { 2 - 6 } & $\mathbf{1 9 7 1}$ & $\mathbf{1 9 8 0}$ & $\mathbf{1 9 9 0}$ & $\mathbf{2 0 0 0}$ & $\mathbf{2 0 1 0}$ \\
\hline $15-19$ & 109 & 93 & 109 & 99 & 103 \\
\hline $20-\mathbf{2 4}$ & 88 & 90 & 91 & 93 & 101 \\
\hline $25-29$ & 135 & 106 & 97 & 93 & 101 \\
\hline $30-34$ & 87 & 103 & 111 & 102 & 105 \\
\hline $35-39$ & 117 & 94 & 117 & 104 & 103 \\
\hline $40-44$ & 96 & 110 & 108 & 121 & 106 \\
\hline $45-49$ & 133 & 109 & 117 & 124 & 108 \\
\hline $50-54$ & 100 & 124 & 124 & 121 & 115 \\
\hline $55-59$ & 129 & 118 & 97 & 104 & 120 \\
\hline $60-64$ & 113 & 102 & 118 & 112 & 106 \\
\hline $65-69$ & 110 & 102 & 113 & 101 & 99 \\
\hline $70-74$ & 130 & 118 & 97 & 114 & 90 \\
\hline $75+$ & 127 & 104 & 93 & 94 & 79 \\
\hline
\end{tabular}

Sumber: BPS dengan pengolahan, 2016

\section{Rasio Ketergantungan}

Rasio ketergantungan atau dependency ratio (DR) adalah nilai yang menunjukkan seberapa banyak penduduk peroduktif menanggung penduduk yang tidak produktif (Mantra, 2000). Rasio ini didapatkan dengan membandingkan jumlah penduduk tidak produktif (usia < 15 tahun dan > 64 tahun) dengan penduduk produktif (usia 15 - 64 tahun). Tulisan ini akan manganalisis DR dari tahun $1971-2010$.

Rasio ketergantungan di Bengkulu selalu menurun dari tahun ke tahun (Tabel 4). Hal ini dikarenakan jumlah penduduk produktif terus meningkat dibandingkan penduduk nonproduktif. Tahun 1970 merupakan nilai DR terburuk yang dimiliki Bengkulu (DR senilai 107). Hal ini berarti setiap 100 penduduk produktif harus menanggung 107 penduduk non produktif. Sementara itu, tahun 2010 merupakan DR terbaik yang dimiliki yaitu senilai 52. Hal ini berarti setiap 2 orang produktif menanggung 1 orang tidak produktif.

Rasio ketergantungan tersebut dapat menjadi indikator kemajuan ekonomi Bengkulu. Hal ini diartikan ketika rasio ketergantungan tinggi maka pertumbuhan 
ekonomi terganggu atau penghasilan masyarakat rendah, sementara itu rasio yang rendah dapat memicu pertumbuhan ekonomi yang tinggi.

Tabel 4: Rasio Ketergantunan Tahun 1971-2010

\begin{tabular}{|c|c|c|c|c|c|}
\hline Tahun/Keterangan & $\mathbf{1 9 7 0}$ & $\mathbf{1 9 8 0}$ & $\mathbf{1 9 9 0}$ & $\mathbf{2 0 0 0}$ & $\mathbf{2 0 1 0}$ \\
\hline $\begin{array}{c}\text { Jumlah penduduk non } \\
\text { produktif }\end{array}$ & 263,525 & 371,804 & 520,970 & 578,564 & 590,419 \\
\hline Jumlah penduduk produktif & 245,691 & 395,984 & 657,981 & 983,541 & $1,125,099$ \\
\hline DR & 107 & 94 & 79 & 59 & 52 \\
\hline
\end{tabular}

Sumber: BPS dengan pengolahan, 2016

Rasio ketergantungan dipengaruhi oleh jumlah penduduk yang produktif dan tidak produktif. Jumlah penduduk yang tidak produktif disebabkan oleh tingginya penduduk anak-anak atau tingginya penduduk lansia. Provinsi Bengkulu pada tahun 1970 memiliki DR yang tinggi akibat penduduk anak-anak yang tinggi. Disisi lain, penduduk usia kurang dari 15 merupakan suatu asset yang akan menjadi penduduk produktif. Hal ini terlihat dari Tabel 4 dan dimana jumlah penduduk produktif semakin meningkat hingga mencapai DR senilai 52 di tahun 2010.

Tabel 5: Rasio Ketergantungan Provinsi Seluruh Indonesia

\begin{tabular}{|c|c|c|c|c|c|c|}
\hline \multirow{2}{*}{ No } & \multirow{2}{*}{ Provinsi } & \multicolumn{5}{|c|}{ Dependency Ratio (\%) } \\
\cline { 3 - 7 } & & $\mathbf{1 9 7 1}$ & $\mathbf{1 9 8 0}$ & $\mathbf{1 9 9 0}$ & $\mathbf{2 0 0 0}$ & $\mathbf{2 0 1 0}$ \\
\hline 1 & Nanggroe Aceh Darussalam & 90.6 & 85.2 & 77 & 58.3 & 54.3 \\
\hline 2 & Sumatra Utara & 105.64 & 94.66 & 82.03 & 63.48 & 59.04 \\
\hline 3 & Sumatra Barat & 94.22 & 87.46 & 77.45 & 62.23 & 60.22 \\
\hline 4 & Riau & 92 & 84 & 77 & 54 & 56 \\
\hline 5 & Kepulauan Riau & 92 & 84 & 77 & 54 & 46 \\
\hline 6 & Jambi & 91.69 & 83.63 & 73.62 & 55.7 & 51.68 \\
\hline 7 & Sumatra Selatan & 93.32 & 87.26 & 80.33 & 61.82 & 52.24 \\
\hline 8 & Bangka Belitung & 93 & 87 & 80 & 56 & 50 \\
\hline 9 & Bengkulu & 107 & 94 & 79 & 59 & 52 \\
\hline 10 & Lampung & 97.82 & 90.4 & 77.54 & 57.45 & 48.7 \\
\hline 11 & Jakarta & 80.04 & 68.19 & 50.61 & 35.14 & 36.94 \\
\hline 12 & Jawa Barat & 90 & 81 & 69 & 54 & 51 \\
\hline 13 & Banten & 90.11 & 81.09 & 69.91 & 61.86 & 48.66 \\
\hline 14 & Jawa Tengah & 85.04 & 75.22 & 56.78 & 56.04 & 39.53 \\
\hline
\end{tabular}




\begin{tabular}{|c|c|c|c|c|c|c|}
\hline \multirow{2}{*}{ No } & \multirow{2}{*}{ Provinsi } & \multicolumn{5}{|c|}{ Dependency Ratio (\%) } \\
\hline & & 1971 & 1980 & 1990 & 2000 & 2010 \\
\hline 15 & Daerah Istimewa Yogyakarta & 83 & 70 & 54.6 & 44.7 & 45.9 \\
\hline 16 & Jawa Timur & 77.48 & 67.93 & 56.78 & 45.92 & 58.08 \\
\hline 17 & Bali & 87.55 & 77.57 & 55.82 & 45.57 & 41.03 \\
\hline 18 & Nusa Tenggara Barat & 90.27 & 90.52 & 82.25 & 62.96 & 54.57 \\
\hline 19 & Nusa Tenggara Timur & 86.31 & 82.39 & 82.07 & 65.41 & 73.21 \\
\hline 20 & Kalimantan Barat & 86.07 & 83.55 & 78.34 & 54.9 & 54.85 \\
\hline 21 & Kalimantan Tengah & 97.79 & 89.72 & 76.26 & 55.58 & 51.14 \\
\hline 22 & Kalimantan Selatan & 85.82 & 52.21 & 61.67 & 55.85 & 48.7 \\
\hline 23 & Kalimantan Timur & 79.61 & 77.18 & 66.72 & 50.09 & 49.13 \\
\hline 24 & Sulawesi Utara & 92.8 & 85.3 & 60.4 & 48.3 & 50.2 \\
\hline 25 & Sulawesi Barat & 87.28 & 82.13 & 70.77 & 59.01 & 46.77 \\
\hline 26 & Sulawesi Tengah & 56.2 & 52.8 & 41.5 & 57.7 & 58.3 \\
\hline 27 & Sulawesi Tenggara & 96.26 & 99.81 & 87.59 & 68.2 & 61.44 \\
\hline 28 & Sulawesi Selatan & 87.28 & 82.13 & 70.77 & 59.01 & 57.21 \\
\hline 29 & Gorontalo & 92.8 & 85.3 & 60.4 & 56 & 51.7 \\
\hline 30 & Maluku & 95.19 & 87.74 & 109 & 70.54 & 67.17 \\
\hline 31 & Maluku Utara & 95.19 & 87.73 & 109 & 70.54 & 101.6 \\
\hline 32 & Papua Barat & 72 & 78 & 78 & 61 & 55 \\
\hline 33 & Papua & 72 & 78 & 78 & 61 & 56 \\
\hline & Max & 107 & 99.81 & 109 & 70.54 & 101.6 \\
\hline & Min & 56.2 & 52.21 & 41.5 & 35.14 & 36.94 \\
\hline
\end{tabular}

Sumber: BPS dengan pengolahan, 2016

DR suatu daerah senilai 40-50 menandakan terjadinya jendela kesempatan. Provinsi Bengkulu memiliki DR yang mendekati nilai tersebut pada tahun 2010. Pola DR yang semakin menurun memungkinkan daerah ini kelak akan mencapai jendela kesempatan. Adanya peristiwa ini merupakan suatu peluang bagi Bengkulu untuk mencapai kesejahteraan masyarakat karena jumlah penduduk produktif akan tinggi. Disisi lain, hal ini akan menjadi ancaman apabila penduduk produktif tidak mendapat pekerjaan atau ruang.

DR Provinsi Bengkulu apabila dibandingkan dengan seluruh provinsi di Indonesia dapat dilihat pada Tabel 5 dan Gambar 2. Data tersebut menunjukkan bahwa pada tahun 1971 DR Bengkulu merupakan yang paling tinggi. Hal ini menunjukkan bahwa pada tahun 1971 struktur penduduk tergolong muda. 
Piramida penduduk tahun 1971 (Gambar 1) menunjukkan bahwa penduduk dibawah 14 tahun jumlahnya sangat besar. Program pengurangan fertilitas terlihat efektif dari dat temporan tersebut. Seiring berjalannya waktu nilai DR mulai menurun hingga mencapai puncaknya pada tahun 2010 dengan nilai 51. DR Provinsi Bengkulu sejak tahun 1980 mulai tergolong kelas menengah hingga tinggi pada tahun 2010 pada perbandingan seluruh Indonesia.

Gambar 2: Dependency Ratio Indonesia Tahun 1971, 1980, 2000, 2010

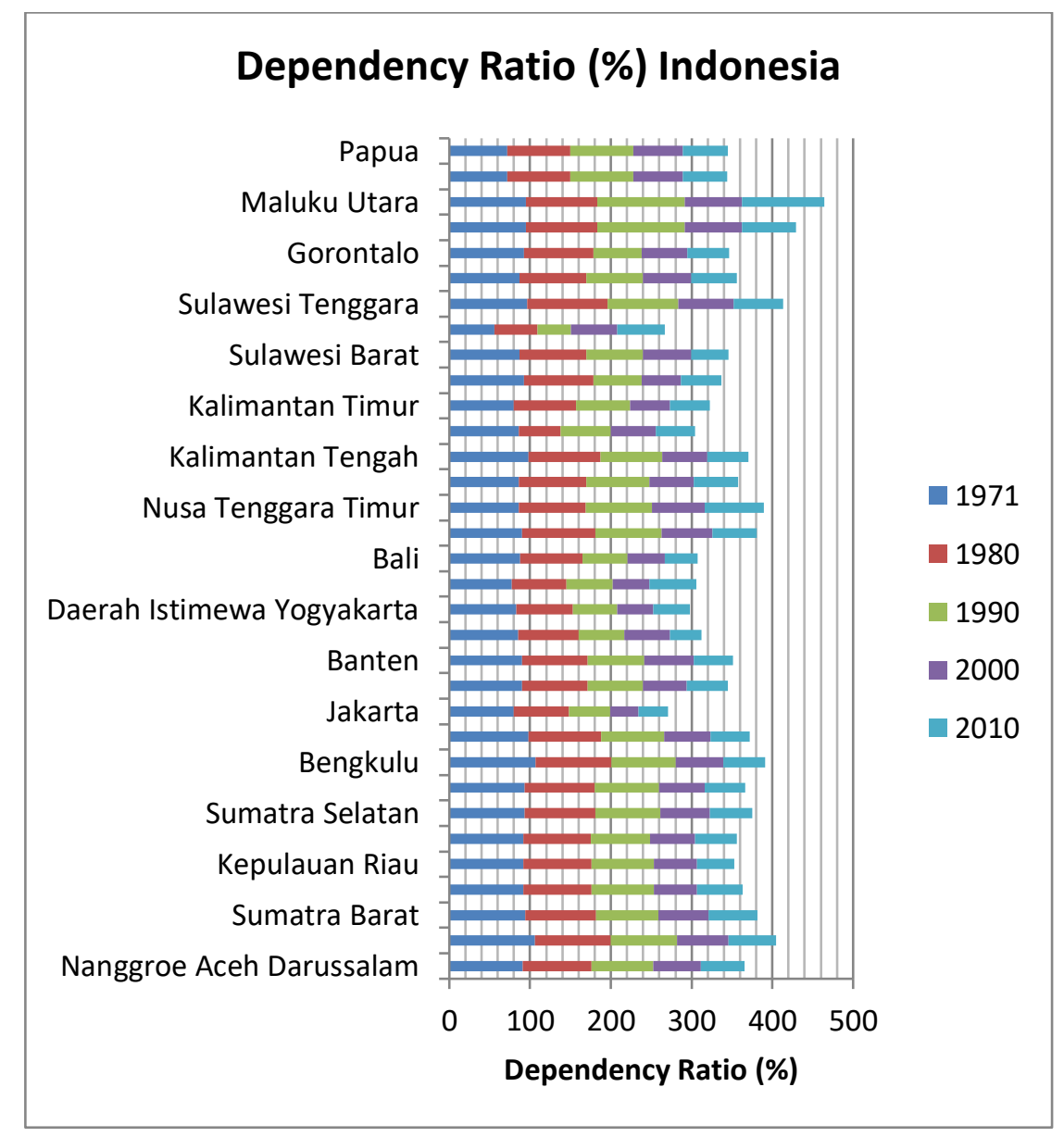

Sumber: BPS dengan pengolahan, 2016

\section{Kepadatan Penduduk}

Kepadatan penduduk merupakan jumlah penduduk per satuan wilayah tertantu (Mantra, 2000). Kepadatan penduduk wilayah terdiri dari berbagai konsep, seperti kasar, fisiologis, agraris, dan ekonomi. Tulisan ini akan 
menganalisis kepadatan penduduk kasar di Provinsi Bengkulu, yaitu membandingkan jumlah penduduk dengan luas daerah keseluruhan tanpa mempertimbangkan wilayah yang dapat dihuni atau tidak dapat dihuni.

Tabel 6: Kepadatan Penduduk Tahun 1971-2010 (jiwa/ $/ \mathrm{km}^{2}$ )

\begin{tabular}{|l|r|r|r|r|r|r|}
\hline Tahun/Keterangan & 1971 & 1980 & 1990 & 2000 & 2010 \\
\hline Luas wilayah & \multicolumn{5}{|c|}{19788.7} \\
\hline Jumlah Penduduk & 509,216 & 767,788 & $1,178,951$ & $1,562,105$ & $1,715,518$ \\
\hline Kepadatan Penduduk & 26 & 39 & 60 & 79 & 87 \\
\hline
\end{tabular}

Sumber: BPS dengan pengolahan, 2016

Kepadatan penduduk di Bengkulu terus meningkat dari tahun ke tahun (Tabel 6). Tahun 1971 setiap 26 penduduk menempati wilayah $1 \mathrm{~km}^{2}$, sedangkan pada tahun 2010 setiap $\mathrm{km}^{2}$ ditempati oleh 87 penduduk. Naiknya kepadatan penduduk tersebut dipengaruhi oleh jumlah penduduk yang juga terus meningkat dari tahun ke tahun. Kepadatan penduduk ini berkaitan dengan kenyamanan dan kesejahteraan manusia tinggal di suatu tempat. Penduduk yang padat menyebabkan fasilitas dan sumberdaya yang ada juga akan dimanfaatkan oleh banyak orang. Oleh karena itu, perlu dilakukan pengukuran terhadap daya dukung wilayah agar dapat diketahui jumlah penduduk optimal yang dapat didukung oleh sumberdaya di Bengkulu.

\section{KESIMPULAN}

1. Rasio jenis kelamin di Provinsi Bengkulu secara umum menunjukkan penduduk laki-laki yang lebih banyak dibandingkan perempuan. Rasio pada tahun 2000 dan 2010 menunjukkan bahwa angka harapan hidup perempuan lebih tinggi dibandingkan laki-laki.

2. Angka ketergantungan semakin menurun pada periode 1971-2010. Hal ini diakibatkan jumlah penduduk produktif yang samakin meningkat. Pola DR ini menunjukkan akan terjadinya jendela kesempatan pada waktu yang akan datang. 
3. Jumlah penduduk di Provinsi Bengkulu pada periode 1971-2010 terus mengalami peningkatan. Hal ini mengakibatkan kepadatan penduduk yang ada semakin tinggi. 


\section{DAFTAR PUSTAKA}

BPS. 2011. Bengkulu Dalam Angka Tahun 2010. Bengkulu: BPS.

BPS. 1971. Sensus Penduduk Tahun 1971. Jakarta: BPS.

BPS. 1980. Sensus Penduduk Tahun 1980. Jakarta: BPS

BPS. 1990. Sensus Penduduk Tahun 1990. Jakarta: BPS

BPS. 2000. Sensus Penduduk Tahun 2000. Jakarta: BPS

BPS. 2010. Sensus Penduduk Tahun 2010. Jakarta: BPS

Mantra, Ida Bagoes. 2000. Demografi Umum. Yogyakarta: Pustaka Pelajar.

\section{DAFTAR LAMAN}

https://id.wikipedia.org/wiki/Bengkulu\#Sejarah. Diakes oleh Afid Nurkholis pada 22 Maret 2016 jam 20.00 WIB. 